\title{
True Hermaphroditism in a Dog: A Case Report
}

\author{
Ebubekir YAZICI'1, Mehmet Fatih BOZKURT², Oktay YILMAZ ${ }^{*}$ \\ ${ }^{1}$ Department of Obstetrics and Gynaecology, Faculty of Veterinary Medicine, Afyon Kocatepe University, 03300 Afyonkarahisar, Turkey \\ ${ }^{2}$ Department of Pathology, Faculty of Veterinary Medicine, Afyon Kocatepe University, 03300 Afyonkarahisar, Turkey
}

\begin{abstract}
True hermaphroditism in a dog is described in this case report. An eight month old cross-breed dog with enlarged structure protruding from the vulva was brought for an ovariohysterectomie operation. Physical examinations exposed the presence of an os clitoris and urethral orifice at the base of the os clitoris. Exploratory laparotomy was performed as a diagnostic and therapeutic procedure. Both gonadal tissues and the genital tract were removed during surgery and brought to the laboratory for pathological examinations. Microscopic examinations showed that the right gonad had both seminiferous tubules like testis and primer follicles like ovarium. The concentrations of serum progesterone, testosterone and $17 \beta$-estradiol were 0,188 ng/ml, 1,008 ng/ml and 23,61 $\mathrm{pg} / \mathrm{ml}$ respectively. We concluded that this is a true hermaphrodismus case due to the simultaneous presence of two sex gonads.
\end{abstract}

Keywords: Dog, Intersexuality, True hermaphroditism, Ovotestis, Hormone concentrations

\section{Bir Köpekte Gerçek Hermafrodismus: Olgu Sunumu}

ÖZ

Bu çalışmada, gerçek hermafrodit bir köpek anlatılmıştır. Vulvasından dışarıya doğru çıkan büyük bir kitle olan 8 aylık melez bir köpek kısırlaştırma operasyonu için araştırma merkezimize getirildi. Fiziksel muayenelerde os klitorisin varlığı ve bunun bazalinde uretral deliğin olduğu saptandı. Teşhis ve tedavi amacıyla hayvana ovariohysterectomie operasyonu uygulandi. Her iki gonadal doku ve uterus patolojik incelemeler için laboratuvara gönderildi. Mikroskobik incelemeler, sağ gonadın hem testis gibi seminifer tubuller hem de ovaryum gibi primer foliküller içerdiğini gösterdi. Serum progesteron, $17 \beta$-östradiol ve testosteron düzeyleri sirasiyla $0,188 \mathrm{ng} / \mathrm{ml}$, 23,61 pg/ml, 1,008 ng/ml olarak ölçüldü. Köpekte her iki gonadal dokunun aynı anda bulunması nedeniyle olgunun bir gerçek hermafrodismus olgusu olduğu kanısına varıldı.

Anahtar Kelimeler: Köpek, İnterseksüalite, Gerçek hermafroditizm, Ovotestis, Hormon seviyeleri

To cite this article: Yazuc E. Bozkurt M.F. Ylmaz O. True Hermaphroditism in a Dog: A Case Report. Kocatepe Vet J. (2019) 12(2):221225.

Submission: 12.07.2018 Accepted: 09.03.2019 Published Online: 16.05 .2019

ORCID ID; EY: 0000-0002-1219-4370, MFB: 0000-0002-1669-0988, OY: 0000-0002-9722-5155

*Corresponding author e-mail: oktayyilmaz@aku.edu.tr 


\section{INTRODUCTION}

The chromosomal sex of zygote resulting in XY or $\mathrm{XX}$ is determined after fertilization. During the normal sex development of males, the SRY gene in the $\mathrm{Y}$ chromosome causes differentiation of primordial follicles in the testes at the sexual differentiation stage of the embryo. Secretion of testosterone and Mullerian Inhibiting Substance (MIS) results in the development of male genital organs. The absence of the Y chromosome and the SRY gene leads to the development of ovaries and female genitalia (Hare 1976, Poth at al. 2010). Any defect at this progression stage may cause the development of sexual disorders such as hermaphrodismus. An animal that has genitalia with a part or all of the genital organs of both sexes is called a 'Hermaphrodite' (Alam et al. 2007). Male pseudohermaphrodites have testicular gonadal tissue with female genital organs, while female pseudohermaphrodites have ovarian gonadal tissue with male genital organs. As for true hermaphrodites, they have the gonadal tissues of both sexes (Hare 1976). There are various combinations involving the presence of both ovarian and testicular tissues in true hermaphrodites. A testis and ovary may be found in contralateral sides, ovotestis may be found in both sides or the ovotestis may be paired with one ovary or testis (Alam at al. 2007). Poth et al. (2010) classified the reproductive tract abnormalities into three categories as sex chromosomes, gonadal sex development and phenotypic sex development disorders. Developmental disorders like these are caused by genetic or chromosomal abnormalities and iatrogenic hormonal or chemical exposure (PaselloLegrand and Mowat 2004). Hermaphroditism is generally reported to be rare in dogs and it is often associated with infertility (Hare 1976, Kim and Kim 2006). In this paper, we report a case of true hermaphroditism in a dog.

\section{CASE HISTORY}

A cross bred dog aged 8 months was brought to the Veterinary Health, Practice and Research Centre of Afyon Kocatepe University for an ovariohysterectomie. The owner noted that the dog was classified as a female at birth and no abnormalities were reported except the absence of estrous behavior and an enlarged clitoris. The initial examination of the external genital organs revealed that an enlarged clitoris protruded from the vulva (Fig. 1). It was approximately $4 \mathrm{~cm}$ in length and 0,5 $\mathrm{cm}$ wide. Palpation of the enlarged tissue indicated the presence of an urethral orifice at the base of the os clitoris. During transabdominal ultrasonography, neither follicles nor pathological structures were observed on the ovaries. Blood samples were collected for sex hormone analyses and it was decided to perform exploratory laparotomy for diagnosis and treatment.

The dog was administered $0,04 \mathrm{mg} / \mathrm{kg}$ atropine sulphate (Atropine sulphate inj ${ }^{\circledR}$, Vetaş, Turkey) subcutaneously $30 \mathrm{~min}$ before the surgery. Intra catch i.v. cannula $(18 \mathrm{G})$ was placed into the v. cephalica antebrachii for applying the anesthetics and intravenous solutions. The animal was premedicated with $0,3 \mathrm{mg} / \mathrm{kg}$ midazolam (Dormicum, Roche ${ }^{\circledR}$, Turkey) given intravenously. Induction of anesthesia was performed with $6 \mathrm{mg} / \mathrm{kg}$ propofol (Propofol ${ }^{\circledR}$, Abbott, Turkey) via IV bolus. Following endotracheal intubation, general anesthesia was maintained with $2 \%$ isoflurane (Forane ${ }^{\circledR}$, Abbott, Turkey). The surgical incision was made on the abdominal midline about $2-3 \mathrm{~cm}$ in length. The reproductive internal organs were similar to those of a female dog in the inspection of the abdomen. After two ligations of the ovarian pedicles and the uterine body, both gonadal tissues and the genital tract were removed and brought to the laboratory for pathological examinations. The surgery was concluded in a routine manner by closing the abdominal wall. Additionally the enlarged clitoris protruding from the vulva was removed (clitorisectomy). No complication occurred after the operation.

Uterine horns were $17 \mathrm{~cm}$ in length, left and right gonads were $1 \mathrm{~cm}$ and $2,5 \mathrm{~cm}$ in diameter respectively. Gonadal tissues were fixed in 10\% neutral-buffered formalin, embedded in paraffin wax, sectioned at 5-6 $\mu \mathrm{m}$ and stained with hematoxylin and eosin. In the microscopic examination, there were numerous structures such as degenerative seminiferous tubules containing 2-3 layer cells on basal and primer follicles close to the cortex in the right gonad (Fig. 2) and numerous wide vessels filled with erythrocytes in the left gonad (Fig. 3). Microscopy of the uterine mucosa revealed wide hemorrhages between glands in the lamina propria (Fig. 4). Blood samples were transported to the Faculty of Medicine of Afyon Kocatepe University for measuring serum progesterone, testosterone and $17 \beta$-estradiol concentrations. Hormone levels were determined by electrochemiluminescence immunoassay (ECLIA, cobas e, Roche Diagnostics GmbH, Mannheim, Germany), according to the manufacturer's instructions. The concentrations of serum progesterone, testosterone and $17 \beta$-estradiol were $0,188 \mathrm{ng} / \mathrm{ml}, 1,008 \mathrm{ng} / \mathrm{ml}$ and 23,61 $\mathrm{pg} / \mathrm{ml}$ respectively. 


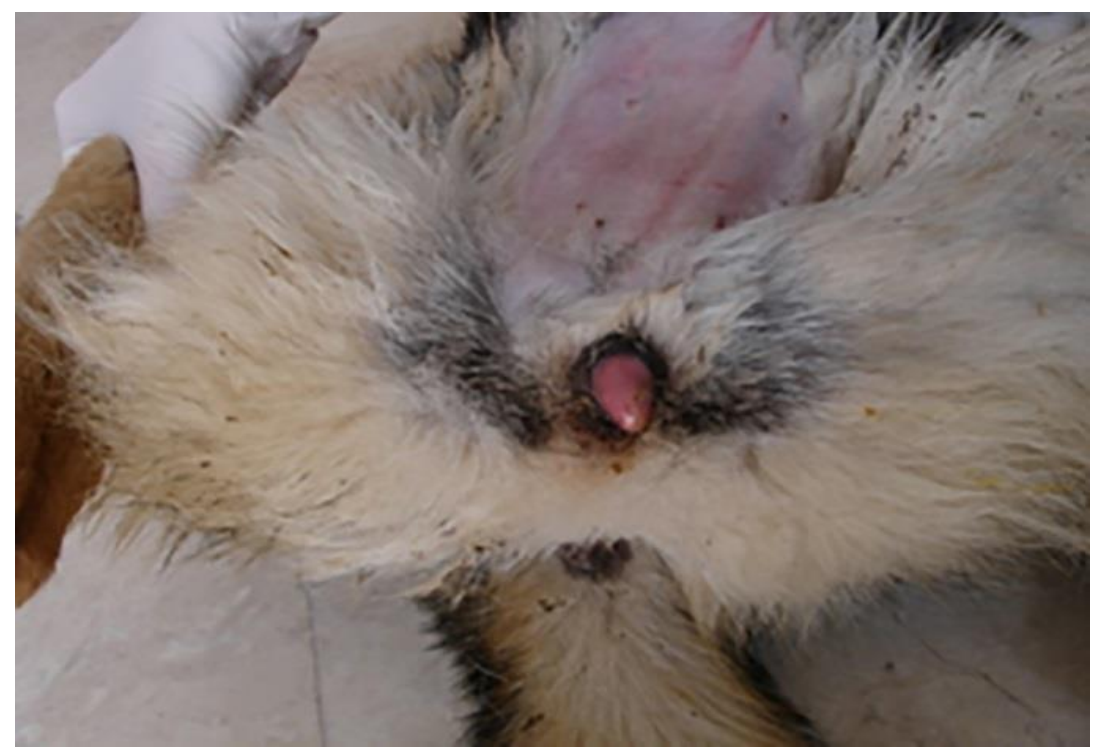

Fig. 1. Enlarged structure protruding from the vulva.

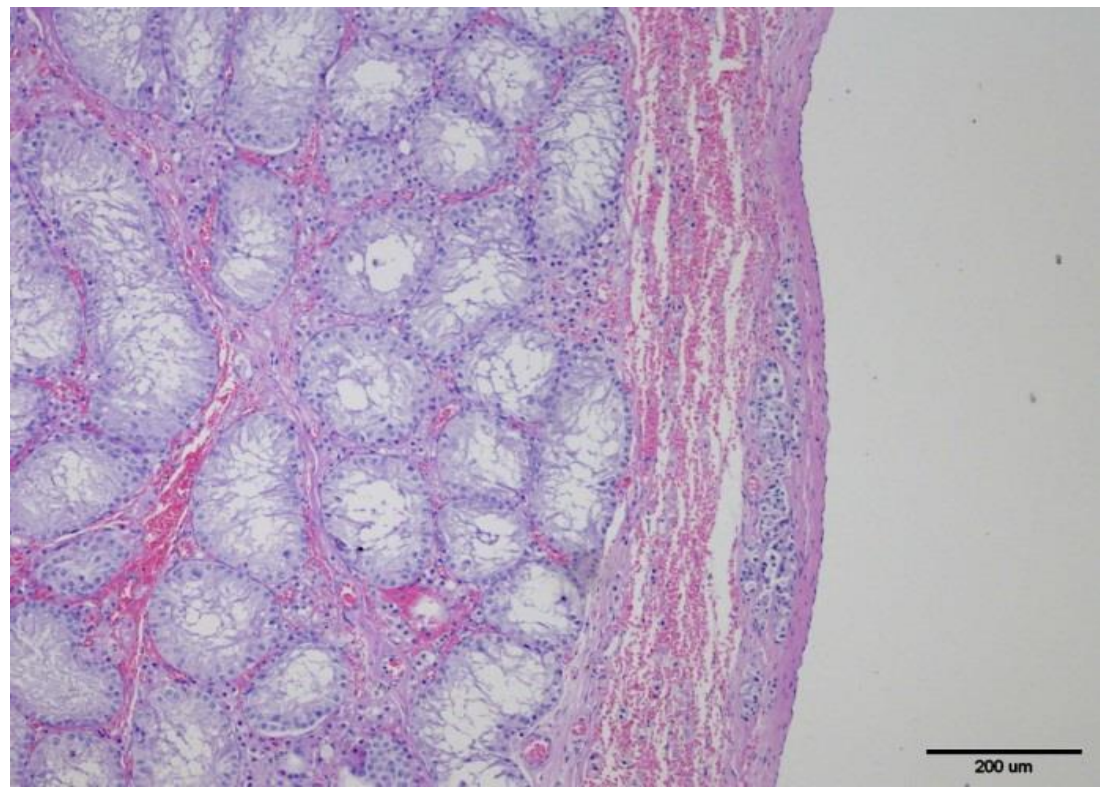

Fig. 2. Right gonad with degenerative seminiferous tubules and primer follicles.

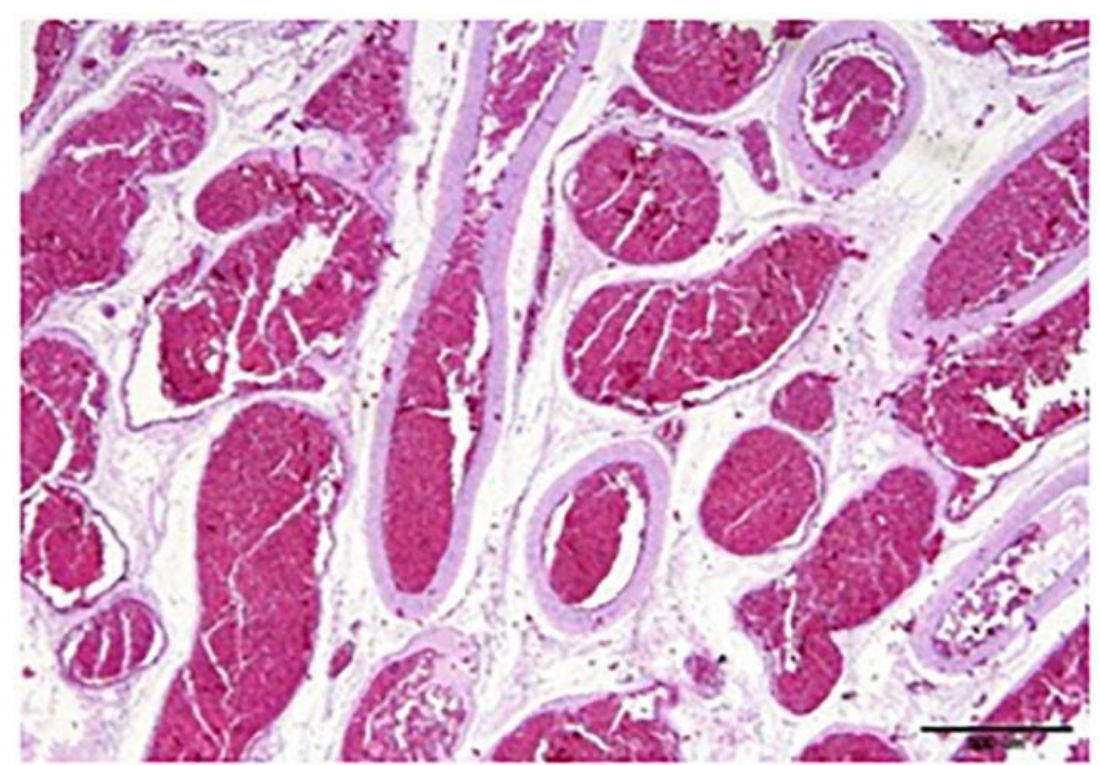

Fig. 3. Left gonad containing wide vessels filled with erythrocytes. 


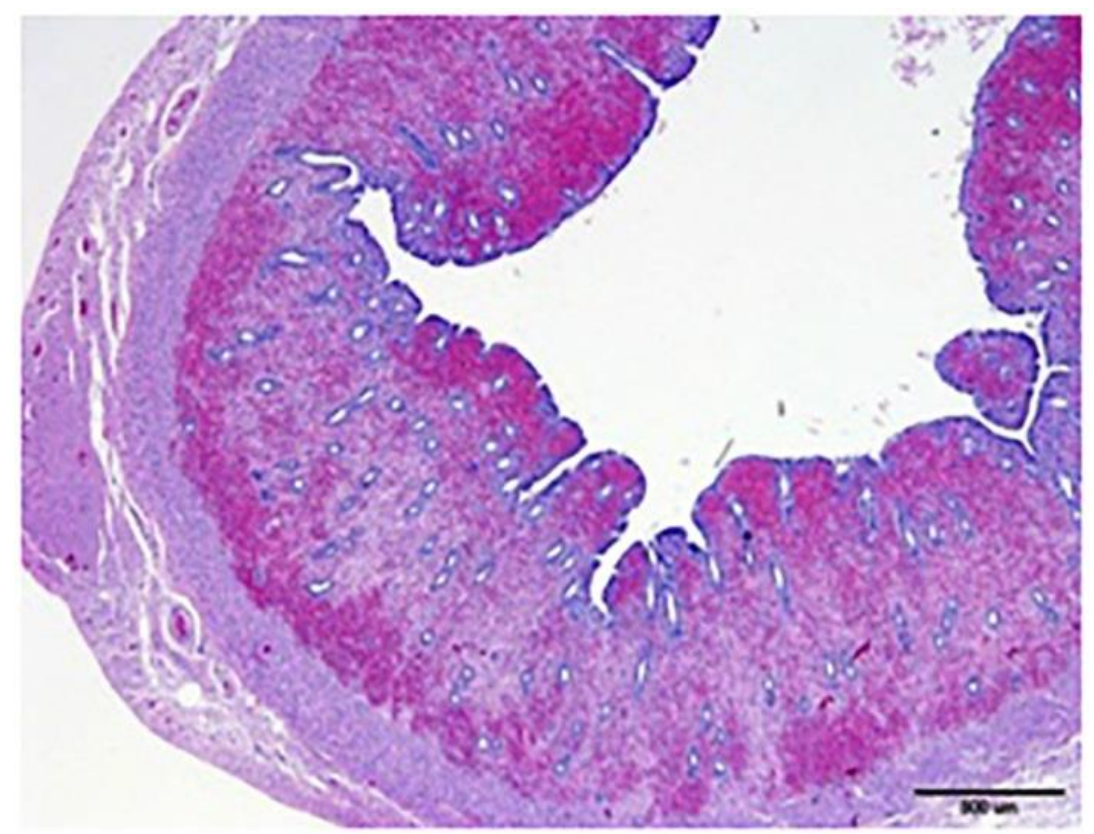

Fig. 4. Uterus

\section{DISCUSSION}

The intersexuality (true hermaphrodismus or pseudohermaphrodismus) in mammals has been described in numerous species including humans, cattle, horses, dogs and monkeys (Atakam 1954, Dunn et al. 1968, Meyers-Wallen et al. 1997, Del Amo et al. 2001, Pasello-Legrand and Mowat 2004). A defect at any step of sexual development, the chromosomal, gonadal or phenotypic level of differentiation can lead to sexual abnormalities (Kim and Kim 2006). Incorrect timing of releasing the Mullerian Inhibiting Factor and inadequate secretion of testosterone by leydig cells can cause the presence of Mullerian and Wolffian structures together in true hermaphrodites (Vani 2008). In this case, a rare condition, true hermaphrodismus, has been reported with the findings of macroscopic, histological and the hormonal profile of a dog.

Serum levels of testosterone, estradiol and progesterone were reported as $0,01-41,5 \mathrm{ng} / \mathrm{ml}, 33,6-$ $66,6 \mathrm{pg} / \mathrm{ml}$ and $0,02-0,5 \mathrm{ng} / \mathrm{ml}$ in healthy male dogs and $0,01-0,3 \mathrm{ng} / \mathrm{ml}, 31,5-69,0 \mathrm{pg} / \mathrm{ml}$ and $0,01-0,65$ $\mathrm{ng} / \mathrm{ml}$ in healthy female dogs, respectively (Concannon and Castracane 1985, Frank et al. 2003). However, we were unable to find any research that reported steroid levels of true hermaphrodite dogs, Del Amo et al. (2001) and Alam et al. (2007) reported hyperestrogenemia and low serum concentrations of testosterone in male pseudohermaphrodite dogs. In this case, the concentrations of serum testosterone were found to be $1,008 \mathrm{ng} / \mathrm{ml}$. The level of testosterone is similar to the basal levels of male dogs but higher than females and male pseudohermaphrodites. It is suggested that the normal testosterone concentrations may be due to true hermaphroditism and the presence of seminiferous tubules. The estrogen level $(23,61$

$\mathrm{pg} / \mathrm{ml}$ ) was lower than that of healthy males, females and male pseudohermaphrodites. Del Amo et al. (2001) suggested that the hyperestrogenemia and low testosterone serum concentrations in male pseudohermaphrodite dogs may be due to the sertoli cell tumors. In the present study, no evidence of sertoli cell tumors has been observed. The serum progesterone level of the patient was similar to that of healthy male and female dogs. Since there were no clear discrepancies regarding the concentrations of progesterone, it might be suggested that there is no association between the concentrations of progesterone and hermaphroditism.

True hermaphrodites have the gonads of both sexes (Alam et al. 2007). Although it is very rare; they can have one testis on one side and one ovary on the other (Atakam, 1954) or ovotestis may be paired with one ovary or testis (Alam at al. 2007). In our case, pathological examinations revealed that there are degenerative seminiferous tubules similar to testis tissue and primer follicles close to the cortex on the right gonad and the other gonad has numerous blood vessels filled erythrocyte. It is suggested that this is a true hermaphrodite dog because of the pathological findings.

Pasello-Legrand and Mowat (2004) reported that hermaphrodismus is caused by genetic or chromosomal abnormalities and incorrect hormonal or chemical exposure. According to the anamnesis, 
no hormonal or chemical treatment was applied to the patient. Therefore, it is suggested that the abnormality originates either from genetic or chromosomal defects. This report describes the first true hermaphrodite case in a cross-bred dog in Turkey.

\section{REFERENCES}

Alam MR, Cho YG, Cho SJ, Lee JI, Lee HB, Tae HJ, Kim IS, Kim NS. Male pseudohermaphroditism in dogs: three case report. Veterinarni Med. 2007; 52(2): 74-78.

Atakam AM. A case of hermaphrodismus masculinus internus. Annals in Surgery 1954; 140(2): 216-222.

Concannon PW, Castracane VD. Serum androstenedione and testosterone concentrations during pregnancy and nonpregnant cycle in dogs. Biology of Rep. 1985; 33(5): 1078-1083.

Del Amo AN, Luca JD, Zufriategui L, Armocida A, Barbeito CG, Gobello C. Male pseudohermaphroditism in a dog: A case report. Communications in Theriogenology 2001; 1(1): $1-11$

Dunn HO, Kenney RM, Lein DH. XX/XY chimerism in a bovine true hermaphrodite: an insight into the understanding of freemartinism. Cytogenetics 1968; 7(5): 390-402.

Frank LA, Rohrbach BW, Bailey EM, West JR, Oliver JW. Steroid hormone concentration in healthy intact neutered dogs before and after cosyntropin administration. Dom Anim Endoc. 2003; 24(1): 43-57.

Hare WCD. Intersexuality in the dog. Can Vet J. 1976; 17(1): 715.

Kim KS, Kim O. A hermaphrodite dog with bilateral ovotestes and pyometra. J Vet Sci. 2006; 7(1): 87-88.

Meyers-Wallen VN, Hurtgen J, Schlafer D, Tulleners E, Cleland WR, Ruth GR, Acland GM. Sry-negative XX true hermaphroditism in a pasa fino horse. Equine Vet J. 1997; 29(5): 404-408.

Pasello-Legrand F, Mowat V. Two cases of spontaneous pseudohermaphroditism in cynomolgus monkey (Macaca fascularis). J Vet Med A Phys Path Cli Med. 2004; 51: 344-347.

Poth T, Breuer W, Walter B, Hecht W, Hermanns W. Disorders of sex development in dog - Adoption of a new nomenclature and reclassification of reported case. Anim Rep Sci. 2010; 121: 197-207.

Vani IA. True Hermaphroditism: Review Article. The Internet J. Pediatrics and Neonatology 2008; 9 (1). 